\title{
湾曲部に設けた側岸凹部流れに関する 実験的研究 \\ EXPERIMENTAL STUDY OF FLOW IN CURVED RECTANGULAR OPEN CHANNEL WITH SIDE CONCAVITY
}

\author{
椿涼太 ${ }^{1} \cdot$ 藤田一郎 2 - 中野淳 3 \\ Ryota TSUBAKI, Ichiro FUJITA and Atsushi NAKANO \\ 1学生会員 神戸大学大学院自然科学研究科後期課程 （广657-8501 神戸市灘区六甲台町 1-1） \\ 2正会員 学博 神戸大学教授 工学部建設学科 （广657-8501 神戸市灘区六甲台町1-1） \\ 3 学生会員 神戸大学工学部建設学科 （厂657-8501 神戸市灘区六甲台町 $1-1 ）$
}

\begin{abstract}
This study aims to clarify the flow structure in curved rectangular open channel with a side concavity. Surface flow velocity profile is measured using PIV technique and bottom flow direction is obtained by a new method using image analysis of bottom streamlines visualized by dye injection method. In curved channel flow, developing process of secondary flow is examined. The structure of channel flow with side concavity in each side is investigated and their differences are clarified. The results show that water level is lager in the casc the side concivity is installed in the outer bank. On the other hand, surface fluctuation is greater in the inner bank case. The aspect ratio of channel width to water depth changed the structure of the flow around side concavity.
\end{abstract}

Key Words : Side concavity, curved open channel, secondary flow, three-dimensional flow structure, flow visualization, PIV

\section{1. 緒言}

近年，河川の親水性向上を目的とし，河川公園の整備 等が進んできた，その中で，河床へのアクセシビリティー 確保を目的として，河岸の片側に払幅部を設け，階段を 設置する（以降，階段工と称する）例が都市部の中小河 川に見られる.このような構造がもたらす流れの抵抗や 変動特性はさまざまな要因が影響する複雑な現象である ため, 設計段階で十分な流況の把握は行われておらず, また設置後の歴史が浅いこともあり，洪水時の水位上昇 量や変動については不明な点が多いのが現状と考えられ る. 藤田ら ${ }^{11}$ は直線開水路において側岸凹部流れの検討 を行っているが，河道の多くを占める，湾曲部に側岸凹 部を設けた際の流れに関する基礎研究例は少ない，そこ で, 本研究では藤田らの従来の研究を湾曲水路に発展さ せ，拡幅部を設けた際の水面形の変化ならびに流れの構 造を明らかにすることを目的とした。

湾曲流れの研究には, Prandt1の流れの三次元的な構造 の分類がある. Prandtlは湾曲流れの二次流を第一種二次 流れと呼び，直線水路にみられる第二種二次流れと区別 した ${ }^{2}$. 最近の研究では冨永・長尾·千葉 ${ }^{3}$ が, 幅水深比を 6あるいは9とした長方形断面の曲がり開水路流れの乱流
計測を目的とし電磁流速計を用いて三次元流速分布を測 定している. また，複数の曲がり開水路により構成され る蛇行開水路流れの乱流計測はShiono・Muto されている.このような湾曲流れの研究で得られた知見 も利用し, 本研究は凹部付近の流れの解明を目指した.

階段工は都市中小河川に設置される例が多いため，本 研究では幅水深比を6および3.75程度, 横断面形は長方 形とし，水位計測，表面流速分布および，底面流線の可 視化から流況の把握を行った. まず，凹部を設けない湾 曲流れにおいて, 基本的な流れの特性を過去の研究と比 較検討した後，凹部を内岸あるいは外岸に設けた場合の 凹部周辺の計測を行った。

\section{2. 実験装置および実験方法}

\section{（1）実験装置}

実験水路の概要を図-1に，平面図を図-2に示す。

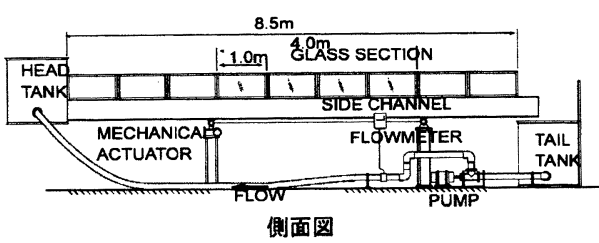

図-1 実験水路の概要 


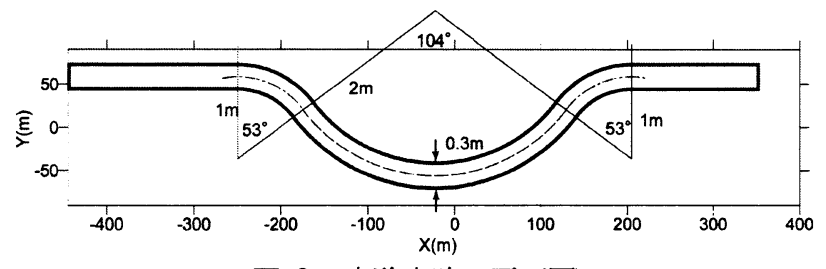

図-2 実験水路の平面図

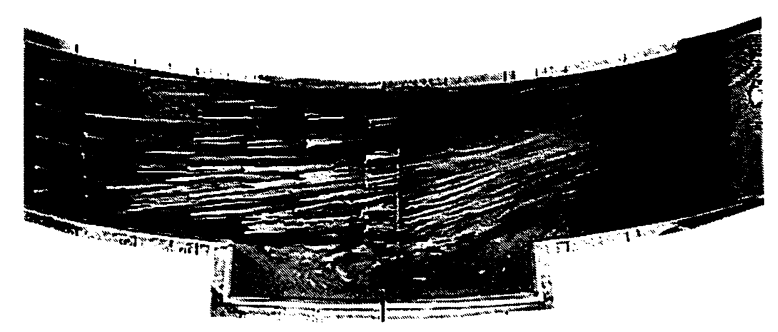

図-3 撮影画像（底面可視化）

実験水路は長さ $8.45 \mathrm{~m}$, 幅 $1.8 \mathrm{~m}$ の水路内に, 水路幅 $0.3 \mathrm{~m}$, 深さ0.1mの長方形断面湾曲水路を設置した. 水路は, 上 流および下流の直線部を第一, 第二, 第三の湾曲水路で 接続したものである. 第一及び第三湾曲部の曲率半径は $1 \mathrm{~m}$ である．第二湾曲部は曲率半径 $2 \mathrm{~m}$ ，角度は $104^{\circ}$ であ る. 湾曲部の組み合わせは, 凹部を取り付ける中央部に おいて発達した湾曲流れが得られるように水路幅および 曲率を調節して配置した. 直線部は木材製とし, 湾曲部 は $1.8 \times 0.9 \times 0.1 \mathrm{~m}$ の発泡スチロールを 6 枚組み合わせて 作成した，木材はペンキ塗装を施し，発泡スチロールは カット後に水路内壁を研摩した. 下流端では堰上げによ り水位を調整した．また上流部には，整流と乱れの均一 化を目的とし粗度を配置した. 流量の調節は二つのバル ブを利用して行い, 流量計測には電磁流量計を用いた. 目盛の最小単位は0.11/sであった。

水深計測にはデジタル式ポイントゲージを用い，表面 流速分布の計測はPIV法を利用した. トレーサーとして, ナイロン破砕粒子（平均粒径 $20 \mu \mathrm{m}$ ）を散布し，側岸上 方から500wのハロゲンランプを二灯設置し，水面を照射 した. 撮影にはSONY製デジタルビデオカメラDCRVX1000を用いた，画像の解像度は720×480pixels，時間 間隔は $30 \mathrm{~Hz}$ のインターレースモードで撮影した. 底面 流線の可視化は白色ポスターカラーを注射器で底面に付 着させ, PIVと同様の方法で画像を取得した(図-3). PIV, 底面流の可視化とも, 河床面を黒色とし, コントラスト の増大を図った. 撮影は水路全体を 7 分割して行い，画 面上に映しこんだ基準点を利用して共通の座標系にまと めた. PIV, 底面可視化の詳細については次節で述べる。

実験条件は勾配 $\mathrm{I}=1 / 500$ とし, 流量を $\mathrm{Q}=7.51 / \mathrm{s}$ おび $15.01 / \mathrm{s}$ と変化させた. この二つのケースの水理条件を 表-1に示す. ここで, 等流水深は直線水路のものを示し ている.

基本ケースは上記の二つであるが，これに第二湾曲部
表-1 水理条件

\begin{tabular}{|l|c|c|c|c|c|}
\hline CASE & $\begin{array}{c}\text { 流量Q } \\
1 / \mathrm{s}\end{array}$ & $\begin{array}{c}\text { 等流水深 } \mathrm{H}_{0} \\
\mathrm{~m}\end{array}$ & $\begin{array}{c}\text { 平均流速 } \\
\mathrm{m} / \mathrm{s}\end{array}$ & $\begin{array}{c}\text { Reynolds数 } \\
U H_{0} / \nu\end{array}$ & $\begin{array}{c}\text { Froude数 } \\
U / \sqrt{g H_{0}}\end{array}$ \\
\hline $\mathrm{Q} 75$ & 7.5 & 0.050 & 0.50 & 28000 & 0.72 \\
\hline $\mathrm{Q} 150$ & 15.0 & 0.080 & 0.63 & 56000 & 0.71 \\
\hline
\end{tabular}

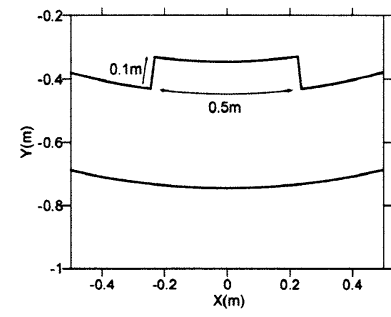

a) 内岸凹部

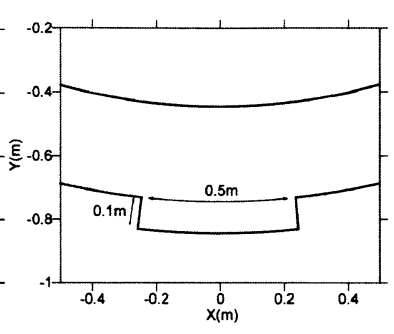

b) 外岸凹部
図-4 実験水路（回部）

の中央の内岸側に凹部を設けたケースをQ75in,Q150in と する. 同様に外岸に設置したケースはQ75out,Q150outと する. 凹部長さは $0.5 \mathrm{~m}$ ，奥行き0.1mとした（図-4）。

\section{(2) PIV}

PIV解析は $0.05 \mathrm{~m}$ 間隔の格子上で行い，テンプレートサ イズは $0.06 \times 0.06 \mathrm{~m}(25 \times 25 \mathrm{pixels})$ とした．解析対象時間 は10秒間とし，300枚の画像を用いて解析を行い，異常 值を取り除いた上で平均操作を行った．異常値は相関係 数およびテンプレートの輝度值の分散にしきい值を設け ることで取り除いた. すなわち, 表面流の可視化ではト レーサーを全面に均一に散布することが難しいため, あ る瞬間にはトレーサーのまばらな領域が現れる.この領 域は輝度值が均一になるため分散が小さくなり, そのテ ンプレートで得られた流速を無効とした.

\section{（3）底面流線の画像計測}

底面流線の計測は，PIV と同様の間隔およびテンプ レートで画像を取り出し, 各画像中の代表角度を抽出し た．具体的には，まず画像中の各点で輝度勾配をもとめ る（図-5a）。ここで，そのまま勾配ベクトルの平均を 取ると, 各べクトルが打ち消しあって, 有効な角度を得 ることができない，そこで, 勾配べクトルの角度を 2 倍 にした後(同b), 領域内でこのベクトルの平均を求め(同 $\mathrm{c})$, 得られた平均ベクトルの角度を 2 で除す(同 d $)$ ことで，画 像の勾配に直行する角度を得ることができる5). 角度を 2 倍することで, 反対向きのベクトル $\left(135^{\circ}, 315^{\circ}\right)$ は 同じ向き $\left(270^{\circ}\right)$ となり, 直行するべクトルは打ち消すこ とができる(図-5aの $45^{\circ}$ と $135^{\circ}$ は図-5bでは $90^{\circ}$ と $270^{\circ}$ と なる). また, PIVと同様, 異常值除去のために輝度値の 分散が一定値以上のテンプレートにおいて得られた結果 を採用した. 図-6に示すのは解析例で, 撮影画像に解析 


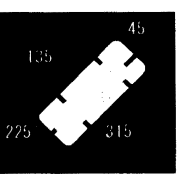

a）勾配ベクトル b) 角度を二倍

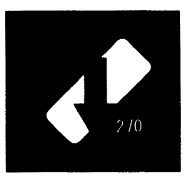

c)平均ベクトル d) 角度を半分
図-5 方向の抽出法

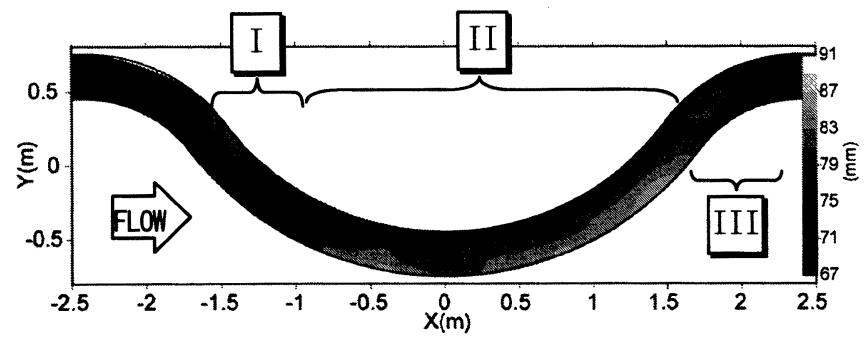

a）水深分布

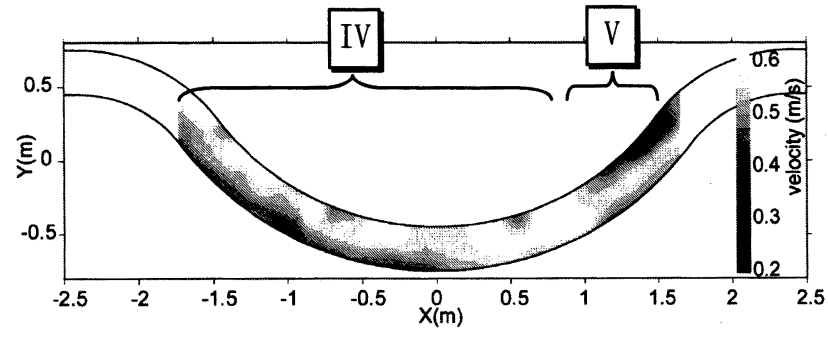

b）流速絶対値の分布

図-7 計測結果 CASE Q150

で得られた流向ベクトルのプロットを合成したものであ る.

\section{3. 実験結果}

\section{(1) 湾曲水路}

凹部を設けない湾曲水路流れ（CASE Q150）の計測結 果を図-7に示す.ここで, 図-7aの太線は等流水深を示 す. 上流部の直線部を通過して, 第一湾曲部に至った流 れは, 左岸にぶつかり左岸側の水位を上昇させ（図中の [I]），X=-1.25m付近で一旦水面が平坦になった後に, [II]にかけて，右岸側の水位上昇が見られる．次に [III]でやや左岸の水位上昇が見られ，水面の平坦な直 線流れへとつながっていく，湾曲流れでは，横断断面内 の圧力勾配によって水位の変化する ${ }^{67)}$. 断面内で，この 圧力勾配と遠心力がつりあい，二次流の発達が促される ことが知られている.

流速分布は，それぞれの湾曲点で内岸が高速，外岸が 低速となる自由渦型分布が見られた。.まず，[IV]におい て内岸側に高速域が確認される。.これは次第に弱まって いき $[\mathrm{V}]$ 付近から, 高速域が反転し外岸が高速となる.

これは下流部の第三湾曲部の影響であるが，水位分布の 反転に先駆けて流速が反転していることが確認できる. 第二湾曲部にみられる平面流速分布の構造は富永らの結
果と共通するものであり，同様の現象が発生していると

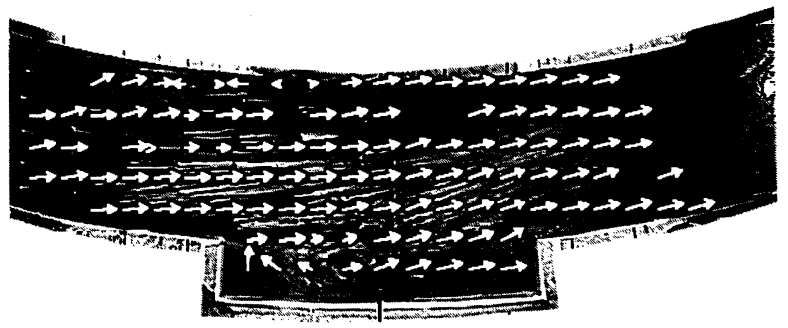

図-6 底面流線の計測 (ベクトルは画像解析結果)

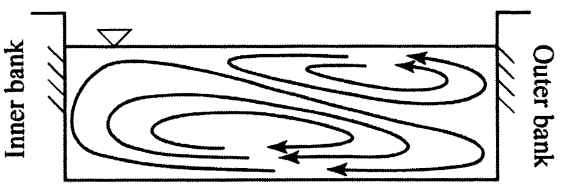

図-8 湾曲部の二次流の概要

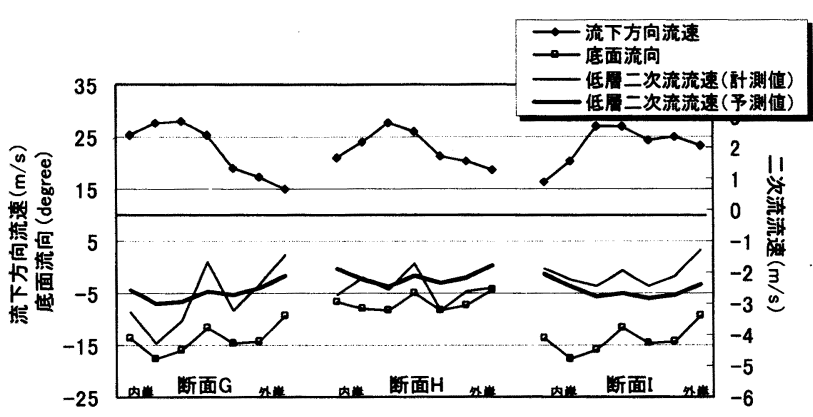

図-9 湾曲部の二次流

考えられる. 富永ら゙ははここの様な区間において内部の 二次流は, 水面で外岸に, 底面で内岸へと向かう流れが 発達するとともに, 外岸上部に逆循環領域がみられるこ とを報告している.

二次流方向の流速は表面付近では流下方向に比べ 1 オーダー程度低く, 表面流計測では精度良く計測するこ とが難しい，そこで，本研究では底面流線分布を利用し て，二次流の強度を推定することを考える. 玉井ら ${ }^{6}$ は 連続湾曲水路流れの構造をタフト法とプロペラ流速計を 利用して明らかにしている. 彼らは, 同じ形状の 90 度 湾曲を交互に10個配置して，これらの位相平均をとり 15 度おきに断面内の流速と, 表面から底面までの流向を計 測した. この中で, 図-8のような湾曲流れの特徵が見ら れる断面での底面流線の方向と表面流下方向流速, 二次 流流速の関係を再整理した結果, 次式のような関係があ ることがわかった.

$$
W \approx 0.52 V_{s}^{0.28} A^{0.28}
$$

ここに, $V_{s}$ : 表面流速 $(\mathrm{cm} / \mathrm{s}), W$ : 底面付近 $(z / h=0.17)$ の二次流流速 $(\mathrm{cm} / \mathrm{s}), A$ : 底面流向 $\left({ }^{\circ}\right)$ であ る.

図-9は玉井らの実験データに著者らの提案式(1)で得 られる予測値をプロットしたものである. 今回はサンプ ル数が少ないため, 関係式には改善の余地はあるが, 底 面付近の二次流の傾向をある程度把握できている. 


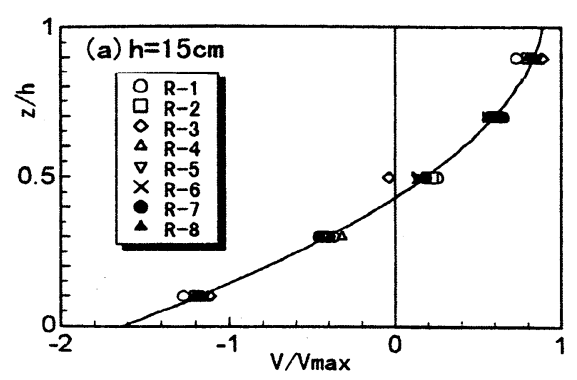

図-10 横断方向流速 $V$ 鉛直分布 $\left(\right.$ 冨永 $\left.5^{3)}\right)$

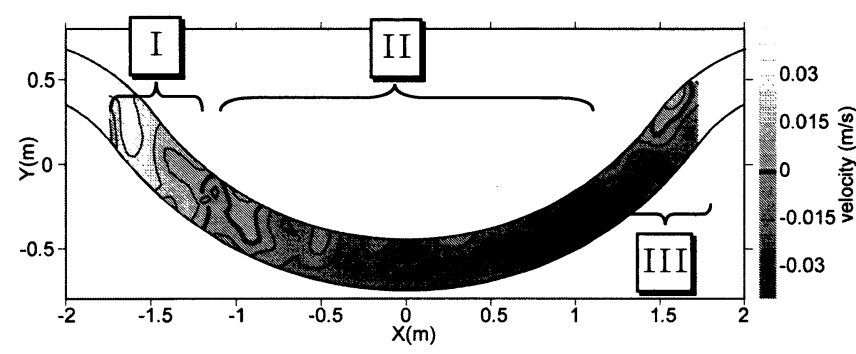

図-11 二次流の分布 (CASE Q75)

富永ら ${ }^{3)}$ によれば水路中央付近での二次流流速分布 (横 断流速成分) は，図-10のような $z / h=0.4$ 付近で $V=0$ となる, 二次式(式-(2))で近似できる. よって，底面付近の二次 流流速は，断面の二次流の強さを代表するものとみなせ る.

$$
\frac{V}{V_{\max }}=a\left(\frac{z}{h}\right)^{2}+a\left(\frac{z}{h}\right)-a
$$

ここに $V$ :横断方向流速, $V_{\max }: V$ の断面内最大値であ る.

ここでは，便宜的に式(1)を用いて底面付近の二次流 流速の推定した(図-11). 正の值は底面で左岸側へ向か う二次流を表す．図中の太線は二次流成分が0であるこ とを示す。これによって，二次流の反転をよび発達を定 性的に確認することができると考えられる.

まず，第一湾曲部を通過した流れには，反時計回りの 二次流成分が生じていることが図の $[\mathrm{I}]$ 付近の分布で確 認できる. 次に, $\mathrm{X}=-1.25 \mathrm{~m}$ 付近で二次流の向きが反転 L, [II] で第二湾曲部の終点付近に向けて時計回りの回 転が発達していく様子を確認することができる，Q75と Q150を比較するとQ150では, 二次流が $\mathrm{x}=1.25 \mathrm{~m}$ 付近で最

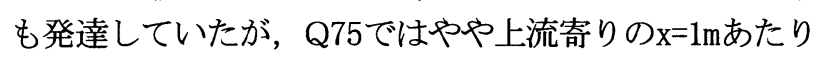
にピークが生じている（図-11）。これは水路幅に対す る水深の違いが影響していると考えられる，Q75での二 次流の反転からピークに達するまでの長さは, X=$1.25 \mathrm{~m}$ から $\mathrm{x}=1 \mathrm{~m}$ までで約 $60^{\circ}$ である．富永らは直線水路 に接続した $90^{\circ}$ の湾曲流れにおいて，二次流のピークは 湾曲開始から $60^{\circ}$ の位置で最大となり, $90^{\circ}$ にかけて若 干減衰すると報告している．本実験とは湾曲の平面形状 や水理条件がやや異なるが，二次流の発達及び消滅過程 は同様の経過をたどることが確認された.

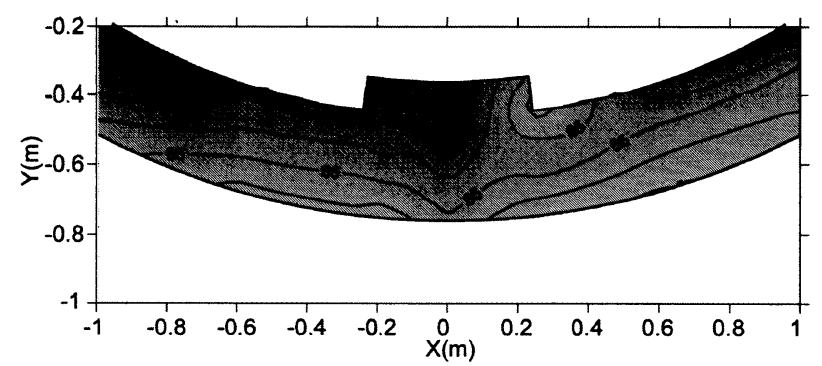

a) CASE Q150in

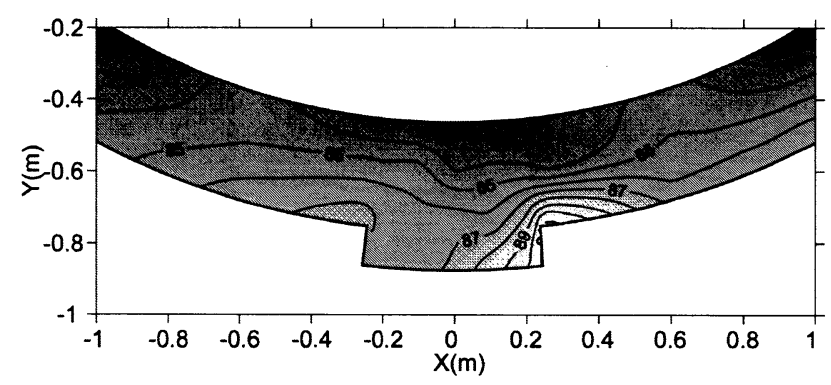

b) CASE Q150out

図-12 水深分布図

\section{（2）側岸凹部流れ}

次に第二湾曲部の中央の側岸に矩形の凹部を設けた場 合の流れを調べた. CASE Q150in,Q150outの水深分布図 を図-12に示す。

水深は基本ケース(図-7a) と比較してどちらも全体的 に上昇している．特に凹部下流端で局所的な上昇がみら れ, 周辺にも全体的な水位上昇が確認できる. 藤田ら ${ }^{177)}$ の直線水路の側岸凹部流れの研究でも同様の傾向が示さ れている. 特に，外岸に凹部を設けたケースではこの二 つの特徴がよりはっきり現れている. 内岸設置のケース では, 基本ケースにおいて内岸の水深が元々低いため, 凹部下流端での水位上昇量は小さい. 凹部周辺の平均的 な水位の上昇は, 内岸に凹部を設けた場合は $5 \%$ 程度, 外岸凹部では $8 \%$ \%どであった.

水面の変動は，特に内岸に凹部を設置した場合に顕著 にみられ，水深変動幅約 $1.5 \mathrm{~cm}$ で周期は約 1 秒の規則的な 振動が確認された.このような変動は直線水路に凹部を 取り付けた場合にみられるもの ¿ $^{8)}$ 同様の現象と考えら れる. 外岸凹部ケースではこのような明確な水面変動は 確認されず対照的であった.

次に, 凹部内部の流れの三次元構造を調べるために時 間平均された表面流速の発散分布を求めた(図-13). 図一 13 の上流側 $(\mathrm{x}=-0.3 \mathrm{~m}, \mathrm{y}=-0.5 \mathrm{~m}$ 付近) では, 発散值が小さ く比較的安定した表層が形成されている. ただし, 図中 の左右壁面付近でみられる発散の変動は, 計測誤差であ ると考えられる。これはPIVでは矩形の領域同士の相関 を用いるため, 壁面近傍では壁面とトレーサー粒子を混 合して計測してしまうからである．内岸凹部ケースでは 主流部と凹部との境界で負の発散領域がみられる。この 


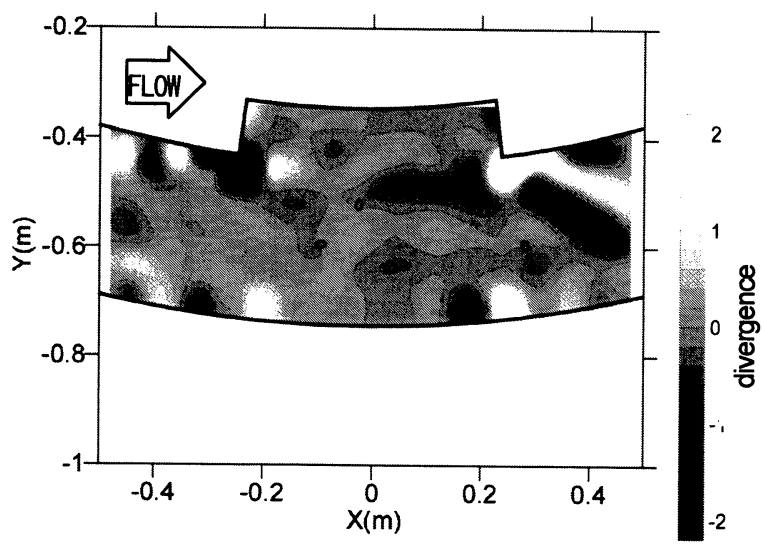

a) CASE Q150in

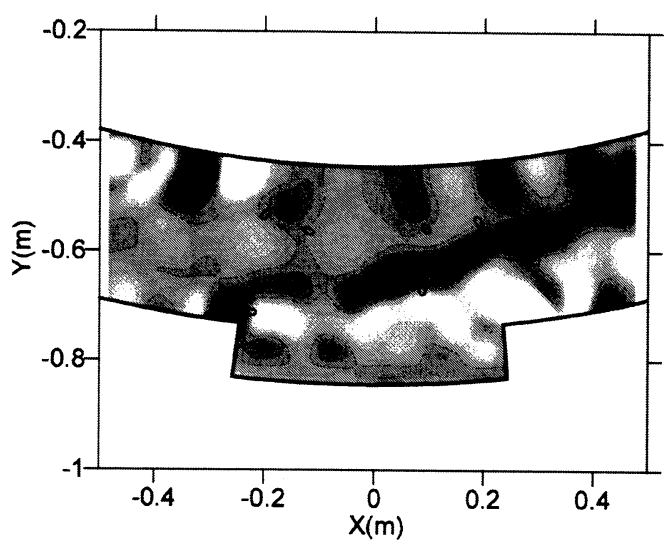

b) CASE Q150out

図-13 表面流速の発散分布

領域はせん断層に対応しており剥離渦の発達がみられる. この剥離渦が表面層を吸い込むように働き表面トレー サーが集められた結果, 負の発散領域が現れたものと考 えられる.この層は，凹部下流端に衝突し，一部は凹部 内の循環流に取り込まれ，それ以外は主流部一合流する が，凹部下流端では衝撃波が発生しており，この波に 沿った流れとなる。この衝撃波は発散分布では強い負の 領域となって現れている．主流部の中央付近を流下する トレーサーもこの衝撃波の影響を受けたのち, 通常の湾 曲流れへと戻っていく.

外岸凹部(図-13b) では，まったく異なる分布がみられ た.このケースでは，凹部の上流端から衝撃波が発生し ており，図中では負の発散領域となっている，次に，主 流部と凹部との境界から凹部内にかけて正の発散領域が 確認される.これは, 凹部内で発生した湧昇流の存在を 示唆している.ここで湧き上がった流れは, 衝撃波に 沿ってやや内岸向きに流下していくため, 凹部下流端一 の衝突は比較的緩やかとなる.

水深計測において，内岸凹部で強い変動が観察される が，外岸凹部では見られないことを述べたが，この変動 は，凹部下流端へのせん断層の衝突が原因であると考え ることができる.内岸凹部ケースでは凹部下流端で強い 衝突がみられ，また凹部内に循環流が形成されることが 振動を引き起こすが，外岸凹部ケースでは，下流端への

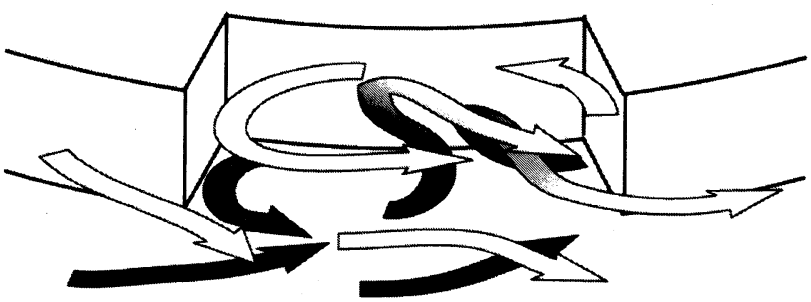

a) CASE Q75in

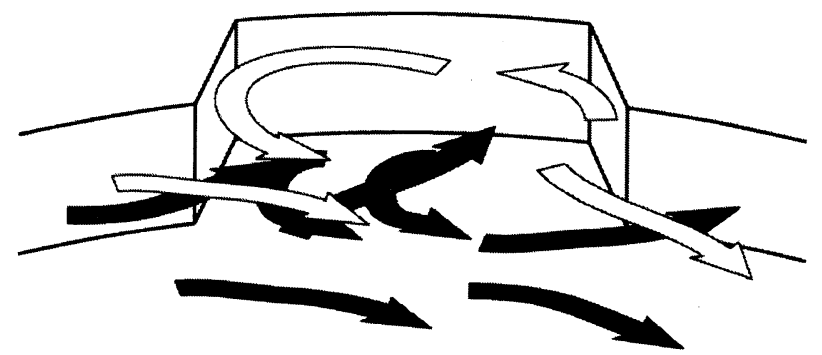

b) CASE Q75out

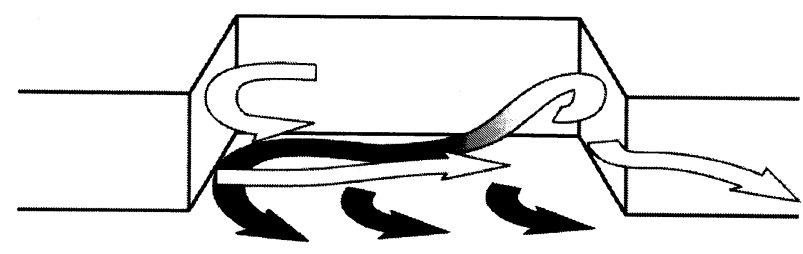

c）直線水路の凹部流れ

図-14 流れの推定図

衝突が緩やかであり，凹部内の流体塊は凹部上流端に発 する衝撃波に沿って速やかに主流部一と流下していくた め, 周期的な振動が発生しないものと考えられる.

内岸凹部のケースでは主流部に投下されたトレーサー の一部はせん断層に取り込まれた後に凹部内に入るが,

外岸凹部では主流部のトレーサーは衝撃波によって内岸 へ集まるため，四部内にはほとんど流入することはな かった.

底面流線は，内岸凹部ケースでは内側へ向かう流れが， また外岸凹部ケースではほぼ平行な流れがみられた。田 部内部では, 流速が小さく, 三次元的な乱れも強いため 本研究の手法では底面流線を計測することができなかっ た. 従って, 染料によって可視化された流れの目視観測 によってえられた凹部内の流線, 表面流速分布, および 発散分布の計測結果に基づいて推定した流れの三次元構 造を図-14に示す．また，比較のために直線水路での凹 部流れ ${ }^{7}$ の推定構造も示した.

まず，比較的水深の低いQ75in,Q75outでは次のような 流れの構造が考えられる. なお，矢印は平均的な流れを 示し, 黒は低層, 白は表層での流れを現している.

内岸凹部(CASE Q75in)の場合は，低層から凹部内人 入り込み凹部内で乱流拡散を伴いながら上昇し, せん断 層の剥離渦によって主流部との運動量の交換を経て主流 部へと合流する.これは，凹部を設けない湾曲流れでは 


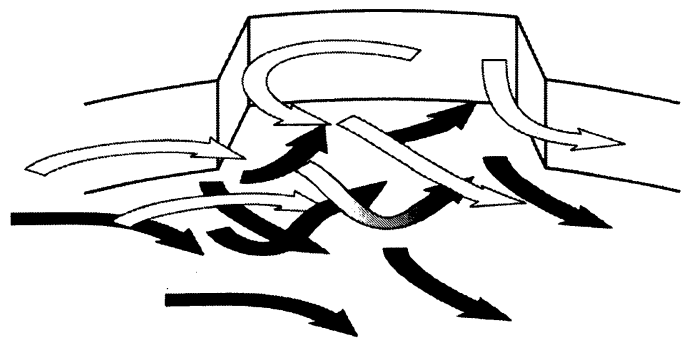

図-15 流れの推定図（CASE Q150out）

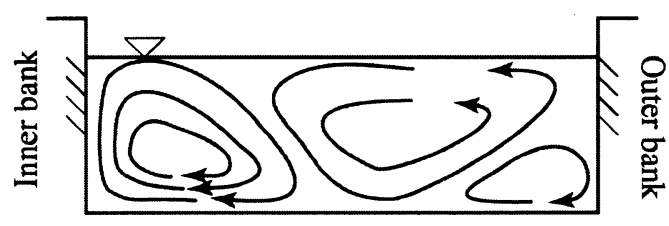

図-16 Q150outの二次流（凹部上流部）
内岸で低層から表層へと向かう流れが存在するが, この 流れが凹部内まで入り込んだものと考えられるからであ る. 凹部内の水平循環は凹部全体に渡る大規模なもので ある点が特徴的である. また, 凹部と主流部との運動量 交換は，低層から入り込み，上層から押し出される循環 によるものと, せん断層での剥離渦に起因寸る混合によ るものがあると考えられる.

外岸凹部(CASE Q75out)の場合は, 中間層から凹部内 に入り込み，表層から主流部一と合流して流下寸る. 凹 部内の水平循環は上流側に生じており内岸凹部より規模 が小さく安定している.これは内岸凹部に比べ，凹部と 主流部の境界でのせん断層があまり発達せず, 表層にお いて凹部と主流部が一体となって流下していくためであ る. 凹部と主流部との流れの交換は，主に中間層から入 り, 表層から押し出される流れによって行われる. 低層 に比べ, 中間層や表層は流速が速いため, 内岸凹部より 外岸凹部は速やかな質量・運動量交換が行われる.この ことが, 外岸凹部の場合に凹部周辺の水位上昇が強く起 こる原因となっていると考えられる.

CASE Q150inの流況はCASE Q75inとほぼ同様であっ た.CASE Q150outは図-15に示したような流れが観察さ れた.このケースでは底面流線から上流端の底面で流れ が集中する領域が確認された。これは表面での衝撃波と 同様の分布であったことから, 四部上流部（図-13の $\mathrm{x}=-$ $0.4 \mathrm{~m}$ 付近の横断面）では図-16のような二次流が発生し ていると考えられる.

図-8の二次流には見られない，外岸側底部の循環流が 凹部の上流 $(\mathrm{x}=-0.4 \mathrm{~m}$ 付近) で発生していており, これ によって凹部周辺の流れがより複雑なものとなっている. この循環流は，Q75outに比べてQ150outの水深が大きい ため, 流れの三次元性が強くなることが原因と考えられ るが，凹部のないQ150では見られなかったことから， 凹部の存在がこの循環の発生の要因になっていると考え られる。

\section{4. 結言}

湾曲部に設けた側岸凹部流れについて実験的検討を 行った．流れの三次元的な循環を捉えるために，PIVに よる表面流速分布および染料の塗膜法による底面流線の
計測を行った，底面流線は画像処理によって，各点での 流向の分布を得ることができた. 四部を設けない湾曲流 れにおいて, 表面流速と底面流向から二次流の流速を推 定する式を提案し，これを利用して，従来の研究と同様 の二次流の発達経過を確認することができた，次に凹部 を設けた湾曲流れに見られる水位上昇と凹部周辺の流れ を調べ, 内岸凹部は外岸凹部に比べ，

a）周期的な強い変動が見られる

b）大規模な水平循環がみられる

c）水位上昇量が少ない

d）主流部との質量・運動量交換が小さい という結果が得られた. また内岸凹部ケースでは四部下 流端から衝撃波の発生が見られるが，外岸凹部ケースで は凹部上流端から発生するという相違がみられた. 今後 は, 凹部のアスペクト比や設置場所による影響を詳細に 調べるとともに, 数值シミュレーションによる検討も行 う予定である.

\section{参考文献}

1) 藤田一郎, 椿涼太, 熊城秀輔: 側岸凹部の形状変化が開水路 流に与える影響, 応用力学論文集, Vol.6, pp.967-974, 2003.

2) Nezu, I. and Nakagawa, H.: Turbulence in open-channel flows, Balkema, 1993.

3) 冨永晃宏, 長尾正志, 千葉茂樹: 幅水深比の小さな長方形断 面開水路の湾曲部流れ構造に関する実験的研究，土木学会論 文集, No.607/ II -45, pp.19-28, 1998.

4) Shiono, K. and Muto, Y.: Complex flow mechanisms in compound meandering channels with overbank flow, J. Fluid Mech., Vol.376,pp.221-261, 1998.

5) 平工良三: 単視点粒子画像を用いた三次元非定常流場計測法 の開発に関する研究, 大阪大学博士論文, 2000 .

6) 玉井信行, 池内幸司, 山崎晶: 連続わん曲水路における流れ の実験的研究，土木学会論文報告集, 第331号, pp.83-94, 1983.

7) 杉山均, 秋山光庸, 龟澤正之: 曲がり開水路乱流の構造解析 と二次流流れ遷移に関する研究，土木学会論文集，No.572/II40, pp.11-20, 1997.

8) 藤田一郎, 小沢純, 長浜弘典: 直線開水路に設置された側岸 凹部が主流に与える影響について, 応用力学論文集, Vol.4, pp.549-556, 2001.

(2003. 9. 30受付) 